ISSN 2074-7888, Наукові праці Донецького національного технічного університету, серія

"Проблеми моделювання та автоматизації проектування" №1 (14), 2019

\title{
ABOUT FEATURES OF MANAGEMENT PREPRODUCTION OF ELECTRONIC VEHICLES
}

Victoria Smolij

\begin{abstract}
As a result of undertaken studies new conception of management is worked out by designer preproduction of electronic vehicles, leaning against single informative space of arrangement of electronic vehicle, operative management designer preproduction and control system by the resources of enterprise, allowing to promote management efficiency designer preproduction of electronic vehicles.
\end{abstract}

Key words: designer preproduction, electronic vehicle, management conception, informative space, arrangement of electronic vehicle, operative management, resources of enterprise, system of support of making decision.

Introduction. The offered conception of management embraces the next stages of creation of electronic vehicle designer preproduction of electronic vehicles: arrangement, constructing, preproduction, test and directly production of preproduction model of good [1, 3 - 5].

Analysis of recent research and publications. The feature of the offered conception of management of designer preproduction of electronic vehicles is that, leaning against single informative space of arrangement of electronic vehicle, operative management designer preproduction and control system by the resources of enterprise, a cost and prime price of preproduction model of electronic vehicle cutout is arrived at; reduction of terms of producing of new electronic vehicles; the competitiveness of enterprise rises at upgrading of electronic vehicles, reliability, oscillation and resonant stability $[2,6,14]$.

An achievement such of results is maybe by means of application of the developed system of support of making decision, realizing a management the systems of arrangement and designer preproduction and their cooperation in single informative space, that changes maintenance of designer preproduction in a root, orients a management arrangement of electronic vehicle on the resources of enterprise, providing management efficiency designer preproduction on the whole $[5,8,16]$.

Purpose of research. For an enterprise producer of electronic vehicles there is providing of management efficiency, including minimization of material production inputs new good or good with the parameters of quality and reliability, excelling analogues, reduction of duration of process of production etc., maybe by the decision of management task exactly designer preproduction by means of choice of arrangement, parameters and properties of producible block of electronic vehicle (exactly as the completed structurally executed good).

Materials and methods of research. For realization of management conception it is necessary designer preproduction of electronic vehicles without the changes of technical equipped of production on the whole to modernize control system only. It is necessary to work out the system of support of making decision, providing with a managing personnel facilities, methods and instruments, providing possibility to realize the offered conception of management $[7-11,15]$.

Results and Discussion. The conceptual model of the automated management of designer preproduction of electronic vehicles looks like, brought around to a fig. 1. The designer preproduction implies producing of preproduction model of good with the parameters of quality, excelling analogues on condition of cost and unit cost cut out and reduction of terms of producing of good [16 - 19].

By analogy with existent classification of CASS of planning, making, tests of and other, the functions of components of the developed system of support of making decision of designer preproduction of electronic vehicles are analogical to the functions of ERP-, MES-, PDM-systems, applied on the enterprises of instrument-making industry $[12,20]$. Application of the functions realized in the developed system of support of making decision analogical to the functions executable PDM - by the system, provides integration of data about arrangement of electronic vehicle, got as a result of planning and design. The constituent of the 
ISSN 2074-7888, Наукові праці Донецького національного технічного університету, серія

"Проблеми моделювання та автоматизації проектування" №1 (14), 2019

developed system of support of making decision of designer preproduction, realizing the functions of PDM, are the systems, executes a management data about electronic vehicles, including the design of electronic vehicle as an object of designer preproduction and management by arrangement of electronic vehicle $[13-15]$.

Data about electronic vehicles

Changes

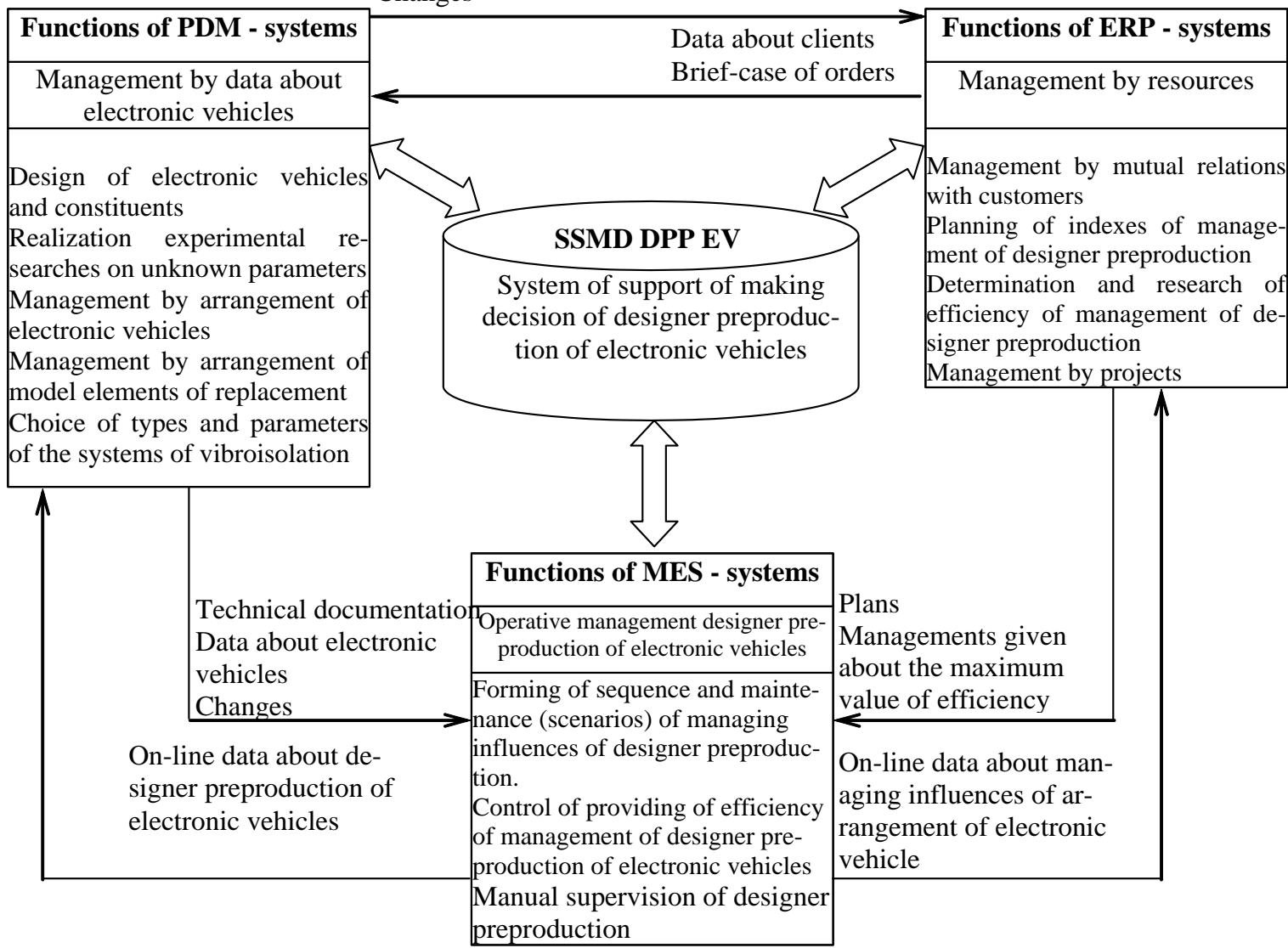

Fig. 1 - Conceptual model of the automated management of designer preproduction of electronic vehicles

Functions of MES - the systems in the developed system of support of making decision of designer preproduction of electronic vehicles suppose implementation of operative management designer preproduction of electronic vehicles on the basis of generated by the system of support of making decision of management scenarios realizing optimal maintenance and sequences of operations of arrangement on condition of observance of condition of management efficiency designer preproduction on the whole [14].

The constituent of the developed system of support of making decision of designer preproduction, realizing the functions of ERP, are the systems, organizes interrelation with the customer of company-producer of electronic vehicles, management by the developed projects and determines the possible size of management efficiency designer preproduction of electronic vehicles, that will allow to the company to produce competitive good, save the markets of sale and get a profit at minimum material production inputs preproduction model of good.

The developed system of support of making decision of designer preproduction of electronic vehicles supposes an association and active cooperation of functions of the examined systems with the purpose of achievement of the required properties, quality, reliability, to resonant and oscillation stability of electronic vehicles on condition of minimization materially - technical production inputs, achievement of cost expended on retraining and in-plant training of personnel effectiveness, expenses on consultative services of experts etc.

The system of support of making decision designer preproduction of electronic vehicles 
ISSN 2074-7888, Наукові праці Донецького національного технічного університету, серія

"Проблеми моделювання та автоматизації проектування" №1 (14), 2019

supposes implementation of functions of design of electronic vehicle taking into account setting and supposed external environments with the purpose of receipt of great number of effective decisions on a management by arrangement of electronic vehicle for the achievement of the required parameters of quality, reliability, oscillation and resonant stability of electronic vehicles. Realization of similar arrangement is possible by the managing affecting of designer preproduction, providing the achievement of financial viability of production of preproduction model of good, exception of tests, returns, revision of good, reduction of time, material production inputs and formalizations of knowledge and experience of experts.

In the conceptual model of the automated management the designer preproduction of electronic vehicles is distinguish next basic essence: management efficiency designer preproduction, electronic vehicle, model element of replacement. Every type of essence at the construction of conceptual model appears as a separate rectangle with the name inwardly, thus the dependent types of essences are represented in a double scope.

The attributes of essence appear as ellipses with the name of the attributes connected by a continuous line with corresponding essence (or by a relation). Every type of relation is shown as a rhombus with the name of relation inwardly. Thus a rhombus is surrounded by a double line, if a relation is set between a dependent type to essence, from existence of that it is in dependence. The separate elements of diagram unite continuous lines (determined raising of management task designer preproduction of electronic vehicles) or dotted lines (stochastic raising of management task). Because connections (relations) of corresponding types of essence are not binary, therefore they are connected by no directional ribs.

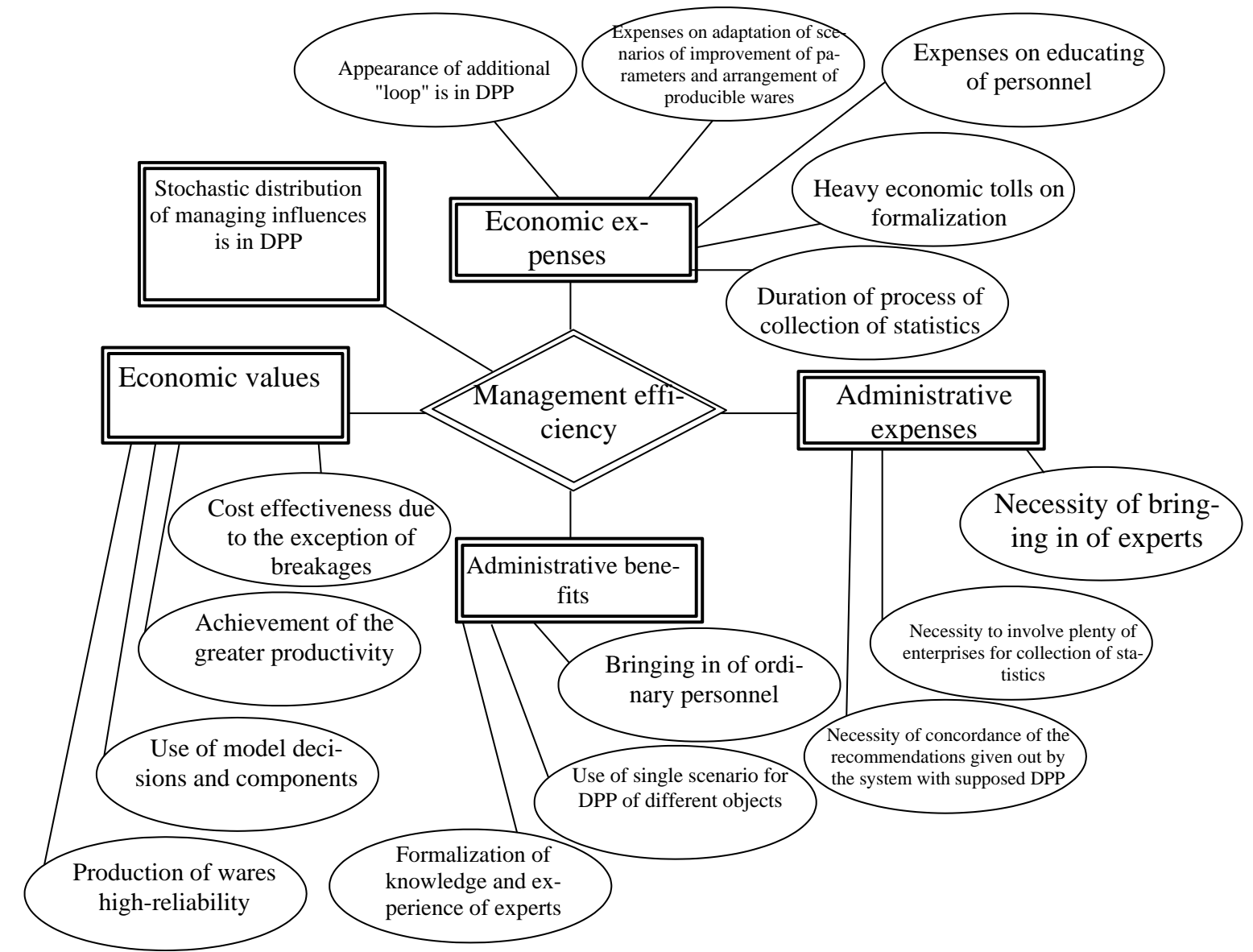

Fig. 2 - Conceptual model of management efficiency designer preproduction of electronic vehicle

It should be noted that for a management the designer preproduction of electronic vehicle is examine the technical and economic indexes of management (management efficiency) and stochastically up-diffused selections of managing influences, divided by teaching and 
ISSN 2074-7888, Наукові праці Донецького національного технічного університету, серія

"Проблеми моделювання та автоматизації проектування" №1 (14), 2019

verification for formalization of management process.

The conceptual model of management efficiency is brought designer preproduction of electronic vehicle around to a fig. 2. On a fig. 2 the attributes of essence are not shown, because we deal with a management designer preproduction of electronic vehicle a few levels of organization are distinguished in that, each of that includes elements from different levels, therefore in detail relations are explained in description to the conceptual model of the system of support of making decision.

Here it should be noted that for a management the designer preproduction of electronic vehicle is examine the technical and economic indexes of management (management efficiency) and stochastically up-diffused selections of managing influences, divided by teaching and verification for formalization of management process.

Management process implementation of certain sequence and maintenance of the managing influences sent both to arrangement of electronic vehicle implies designer preproduction of electronic vehicles and operative management by a personnel and resources of enterprise.

Thus, both for modern firms - producers of domestic electronic technique and for scientific and production enterprises airplane and rocket productions, a management process has identical procedure leaning against subjective presentations and skills of personnel in this area designer preproduction of pre-production model of good.

The unstructured and semistructured multicriterion tasks decide by means of the developed system of support of making decision of designer preproduction of electronic vehicles. The decision of the examined multicriterion tasks will allow not only to improve quality, reliability, resonant and oscillation stability of electronic vehicles, but also to provide financial viability of production of pre-production model of good, eliminate tests, returns on the revision of good, to shorten time, material production inputs and formalized knowledge and experience of experts [15].

In the examined automated management [16] subsystems are distinguished: creations of preliminary character of good, implementation of design of object of designer preproduction, realizations of experimental researches on authentication and research of failing parameters, estimation of quality, reliability, oscillation and resonant stability of electronic vehicle, estimations of management efficiency designer preproduction of electronic vehicles, system of support of making decision, including the subsystems of receipt and treatment of knowledge.

It should be noted that each of them is fully independent and universal for the different sort of tasks, and also each of subsystems is characterized the high degree of noninteraction, that allows to realize the different variants of the parallel including of components of the system and organize an interface for a few users with the simultaneous processing of data.

Examining the computer integrated production of electronic vehicles, characterized by the high degree of automation and application of computer-aided designs, it should be noted that, the object of designer preproduction is characterized repetition, concurrent execution of operations of arrangement and constructing, difficult internal organization.

On an electronic vehicle as an object of designer preproduction is laid on row of requirements on the parameters of quality, reliability, oscillation and resonant stability, it is here necessary to execute the requirements of financial viability and management efficiency designer preproduction, characteristic for the electronic vehicles of the different setting and external environments. All requirements, touching both arrangement and properties of electronic vehicle and management efficiency designer preproduction of electronic vehicle, must be realized in developed system of support of making decision [15].

It should be noted presence and variants of differentiation of the developed system of support of making decision and degree of her use for different on purpose and to composition of objects of designer preproduction.

In the process of functioning the system of support of making decision carries out:

- Ground of necessity of initializing of management process;

- Task of type of object;

- Choice of setting of object;

- Analysis of external environments;

- Prognostication of the possible states of object by means of probabilistic criterion leaning against the base of knowledge and rule of support of making decision;

- Maps the state of object to his components and vice versa; 
ISSN 2074-7888, Наукові праці Донецького національного технічного університету, серія

"Проблеми моделювання та автоматизації проектування" №1 (14), 2019

- Offers methodologies of upgrading, reliability, resonant and oscillation stability of electronic vehicle by means of the offered criteria of arrangement of block of electronic vehicle and constituents;

- Provides the selection of instruments of mathematical design;

- Contains explanations about that, how to work with the instruments of mathematical design;

- Identifies the unknown parameters of mathematical models by realization of experimental researches on a corresponding chart, methodology of the programmatic and technical providing of experiments;

- By means of the worked out criterion of management quality the designer preproduction of electronic vehicles (management efficiency) is watch rationality made alteration in a management designer preproduction of electronic vehicle and their influence is determined on the technical and economic indexes of management on the whole;

- Provides subsequent treatment of control program for a technological equipment, tuned to the same not only under a corresponding technological equipment but also under quality parameters, reliability, oscillation and resonant stability of electronic vehicle.

On the other hand this single cycle of management is mapped to some association of making electronic vehicles, subject to strict hierarchicalness, being with each other in different conceptual relations. It does not allow to talk about possibility of successive implementation of each of operations above some certain object, and supposes the presence of possibility of application of separate operation on the package (great number) of objects or great number of operations on one object, not except possibility of the simultaneous processing of great number of objects.

In the offered conception of management it is assumed designer preproduction, that the type of object for that make an electronic vehicle determines not only external environments but also possibility of bringing of modifications in a management his designer preproduction (management effect), assuming variations of technical and economic indexes and some variations on speed implementations of designer preproduction. The base of knowledge and mechanism of receipt of decision are related to setting of object and object of exploitation, determined by the probabilistic criterion of management efficiency, that systematizes knowledge of experts and experience of specialists engaging in the problem of upgrading and reliability of electronic vehicles.

The variants of terms are possible exploitations that is taken into account in the mathematical model of object, that gives universality in-process designer preproduction the offered management. There is transformation of indexes of quality, reliability, to oscillation and resonant stability of electronic vehicle depending on the results of design on the basis of criteria of arrangement of object of designer preproduction. At changing of mathematical model of electronic vehicle management methodology is applicable designer preproduction either for other external environments or for other objects.

The hierarchy of the prospected objects of designer preproduction is characterized encapsulation, when the elements of subsequent levels consist of great number of elements of previous levels. Such the organization is possible for different objects, what universality of the offered algorithm allows to mark and to reflect his principles on a management by other systems.

Requirements to instrumental part are conditioned by realization of mathematical model as a complex of programmatic and technical facilities, supporting a receipt and transformation of informative character of electronic vehicle in accordance with the criteria of his arrangement. Also the distinguishing feature of instrumental part is methodology plugging in the arsenal of tools of the experimental setting equipped by rigging for authentication of failing parameters of object of designer preproduction.

A return to the management is needed designer preproduction, because virtual building on in form system of support of making decision, including designing complexes, brings in some changes in a structure and parameters of electronic vehicle, that must be passed on a management by designer preproduction and to watch rationality made alteration on the criterion of management quality designer preproduction of electronic vehicles (management effect).

A single algorithm taking into account all these facts differs in large universality and flexibility, because allows to reform on control system designer preproduction of any electronic 
ISSN 2074-7888, Наукові праці Донецького національного технічного університету, серія

"Проблеми моделювання та автоматизації проектування" №1 (14), 2019

vehicles without depending on their informative filling.

In respect of task of type of object, then it the simplified enough classification and scientific and practical interest here present not classification, and standing after it components of probabilistic criterion of management efficiency. The values of components of probabilistic criterion are identified in the process of educating of the system of support of making decision determine, take into account and visualize the base of knowledge of probabilistic descriptions of frequencies of refuses, reasons of refuses, influencing active factors and correlation of technical and economic parameters for a management designer preproduction for the certain type of electronic vehicle and external environments.

The automated management designer preproduction of electronic vehicles is based mainly on dialogue instructions acting on behalf of accepting decision. In order that realization of such possibility took place, it is necessary to supply a person, a decision-making, by instruments, allowing to get, process and analyze information, and mechanism, for preparation of decision-making. To that end it is necessary to build the row of informative, programmatic, technical and intellectual subsystems of the developed system of support of making decision of designer preproduction of electronic vehicles.

Management process implementation of certain sequence and maintenance of the managing influences sent both to arrangement of electronic vehicle implies designer preproduction of electronic vehicles and operative management by a personnel and resources of enterprise. Thus, both for the modern firms of producers of domestic electronic technique and for scientific and productive enterprises airplane and rocket productions, a management process has identical procedure leaning against subjective presentations and skills of personnel in this area designer preproduction of preproduction model of good [16, 19, 20].

The unstructured and semi structured multicriterion tasks decide by means of the developed system of support of making decision of designer preproduction of electronic vehicles. The decision of the examined multicriterion tasks will allow not only to improve quality, reliability, resonant and oscillation stability of electronic vehicles, but also to provide financial viability of production of pre-production model of good, eliminate tests, returns on the revision of good, to shorten time, material production inputs and to build an algorithm knowledge and experience of experts.

Integration of the developed system of support of making decision is arrived at by implementation of row of functions of the systems of production of electronic vehicles, presenting the results of modulating, arrangement and management designer preproduction as data, mechanisms of processing of data and receipt of knowledge making the base of knowledge of the system of support of making decision.

The managing affecting process of designer preproduction acts from outside, in particular on behalf of decision making, in order to ratify the offered scenarios of managing influences of arrangement of electronic vehicle, corresponding to the condition of management efficiency designer preproduction. In a fundamental chart the variant of the use of the developed system of support of making decision is envisaged also for the design of electronic vehicles of the different setting and external environments with the use of the experimental setting for research of failing parameters or additional research of electronic vehicle and constituents.

The offered fundamental chart of the system of support of making decision of designer preproduction of electronic vehicles will realize the mechanism of educating of the system of support of making decision, sent to adaptation of scenarios of achievement of necessary parameters, properties and arrangement of electronic vehicle under the existent terms of financial viability of production and corresponding technical and economic indexes of making of pre-production model of electronic vehicle.

Facial, decision making as the making developed system of support of making decision, it is necessary to distinguish the row of functions:

- preparation of information;

- input of information;

- implementation of design;

- preparation and input of information in the system of support of decision-making;

- analysis of the results got from the system of support of making decision;

- implementation of directive management directly designer preproduction of electronic vehicle, including of necessity executions of the given out recommendations. 
ISSN 2074-7888, Наукові праці Донецького національного технічного університету, серія

"Проблеми моделювання та автоматизації проектування" №1 (14), 2019

For the decision of existent productive situations it is necessary formally to describe the actions of face of decision making, consisting in that his activity is presented by the task of great numbers of requests for implementation: designs, arrangements, operative management designer preproduction, research of management efficiency [14, 17 - 20].

Query on behalf of decision making can touch implementation of design, task of preliminary variant of arrangement, research of resources of enterprise on making of preproduction model of good and their variation.

Person an accepting decision, leaning against subjective knowledge and experience, can obtain the certain indexes of efficiency for some period of time and amount of heuristic iterations, however the developed system of support of making decision, leaning against the mechanisms of educating and multicriterion optimization, allows to bring down expenses and prime price of pre-production model of electronic vehicle; to reduce the terms of producing of new electronic vehicles; to promote the competitiveness of enterprise at upgrading of electronic vehicles, reliability, oscillation and resonant stability; to economize the facilities expended on retraining and in-plant training of personnel, expenses on consultative services of experts etc.

On results a design the system of support of making decision forms the components of criteria of arrangement of electronic vehicles, on results processing of statistical data are criteria of arrangement, on the basis of questioning of experts, from literary sources and statistics are management scenarios designer preproduction, coming from the analysis of technical and economic, skilled and other of indexes of production of electronic vehicles is management efficiency. Synthesizes all these indexes, the system of support of making decision prospects and processes, preparing information facial decision making [14 - 16].

Except the functions of search of optimal scenarios of achievement of the required parameters of quality, reliability, to oscillation and resonant stability of electronic vehicle in the process of designer preproduction the offered system of support of making decision, both produces variants and adapts existing before methodologies oscillation, shock and other variants of defense of electronic vehicles from external influences to the existent economic terms and market mechanisms of development of production of electronic vehicles.

Similar family systematization is possible by means of statistical treatment of results of the expert questioning, formalization of procedure of management and forming of case frames for the certain types of electronic vehicles. Introduction of the offered innovations in the existent chart of management of designer preproduction of electronic vehicles will give an opportunity to tune the prospected management under the certain setting of the produced good and condition of exploitation, to attain optimal combinations of economic and administrative parameters of management designer preproduction of electronic vehicles.

For the achievement of the put aim it is necessary to organize questioning of experts concerning the estimations of priorities of results of application of the offered methodology of management of designer preproduction for different objects with subsequent statistical treatment of results of questioning. It is also necessary to estimate adequacy of the got experimental data, define priorities of parameters and their functional intercommunications and on them to produce the analysis of the got results with organization of feed-back for the estimation of efficiency of management of designer preproduction of electronic vehicles. As a method of decision of this task the method of analysis of hierarchies is applied.

Integration of the developed system of support of making decision is arrived at by implementation of row of functions of the systems of production of electronic vehicles, presenting the results of modulating, arrangement and management designer preproduction as data, mechanisms of processing of data and receipt of knowledge making the base of knowledge of the system of support of making decision [14 - 16].

The managing affecting process of designer preproduction acts from outside, in particular on behalf of decision making, in order to ratify the offered scenarios of managing influences of arrangement of electronic vehicle, corresponding to the condition of management efficiency designer preproduction. In a fundamental chart the variant of the use of the developed system of support of making decision is envisaged also for the design of electronic vehicles of the different setting and external environments with the use of the experimental setting for research of failing parameters or 
ISSN 2074-7888, Наукові праці Донецького національного технічного університету, серія

"Проблеми моделювання та автоматизації проектування" №1 (14), 2019

additional research of electronic vehicle and constituents.

The offered fundamental chart of the system of support of making decision of designer preproduction of electronic vehicles will realize the mechanism of educating of the system of support of making decision, sent to adaptation of scenarios of achievement of necessary parameters, properties and arrangement of electronic vehicle under the existent terms of financial viability of production and corresponding technical and economic indexes of making of pre-production model of electronic vehicle.

Conclusions. New conception of management is worked out by designer preproduction of electronic vehicles, leaning against single informative space of arrangement of electronic vehicle, operative management designer preproduction and control system by the resources of enterprise, allowing to promote management efficiency designer preproduction of electronic vehicles.

First it offers to examine designer preproduction of electronic vehicles as system determined and stochastic constituents, allowing depending on setting of object of designer preproduction to determine management scenarios for the achievement of the required parameters and arrangement of electronic vehicles.

Decision of stochastic task of management the receipt of functional dependences supposes designer preproduction for research of management efficiency including quality and amount of management cycles, allows to optimize the technical and economic and administrative indexes of management, that it is necessary to realize supports of making decision in the developed system.

The worked out conceptual model of the system of support of making decision, leaning against single informative space of arrangement of electronic vehicle, operative management designer preproduction and control system by the resources of enterprise, allows to provide the required properties, quality, reliability, resonant and oscillation stability of electronic vehicles on condition of minimization of material and technical production inputs, achievement of cost expended on retraining and on effectiveness.

Worked out informative and algorithmic providing of management, including the criteria of arrangement and management quality designer preproduction of electronic vehicles, designer preproduction of electronic vehicles, it is necessary to realize supports of making decision in the developed system.

Worked out algorithms of management designer preproduction, choice of types of objects and construction of model of electronic vehicle, including the stages arrangements, constructing, preproduction and tests of electronic vehicle, support intercommunication with the experimental setting with the corresponding rigging, allow to get failing information about the object of designer preproduction and estimate his parameters and arrangement without producing of preproduction model of good.

\section{References}

[1] Aglietti G.S. Development of the MiniSIL ${ }^{\text {TM }}$ Structural design/ G.S. Aglietti, A. Wicks, A.J.Barrington-Brown // Journal of Aerospace Engineering. - Vol 213 part G. - pp. 255-263. 1999. ISSN 0954-4100.

[2] Aglietti G.S. A Lighter Enclosure for Electronics for Space Applications/ G.S. Aglietti //Journal of Aerospace Engineering. - part G, Vol. 216-3. - pp. 131-142. 2002.

[3] Basu K. Soft sets: an ordinal formulation of vagueness with some applications to the theory of choice/ K.Basu, R.Deb, P.K.Pattanaik // Fuzzy Sets and Systems. - №45. - P. 45 - 58. 1992.

[4] Ivakhnenko A.G. Samoorganyzatsyya of the forecasting systems / A.G. Ivakhnenko, I.F. Myuller. - Kyiv: Technique, 1985. - 223. 1985. (in Russian)

[5] Jampolskyy L.S. Flexible computerized systems: planning, design and management / L.S. Jampolskyy, P.P. Melnychuk, B.B. Samotokin, M.M. Polishuk, M.M. Tkach, K.B. Ostapchenko, O.I. Lisovichenko.- Shytomyr: SNTU, - 680 P. + CD. 2005. (in Russian)

[6] La Malfa S. Use of a Dynamic Absorber in the case of a Vibrating Printed Circuit Board of Complicated Boundary Shape / S.La Malfa, P.A.A.Laura, C.A.Rossit, O.Alvarez // Journal of Sound and Vibration. - Vol. 230(3). - pp.721-724. 2000.

[7] Laura P.A.A. Dynamic Stiffening of a Printed Circuit Board / P.A.A.Laura, L.Ercoli, and.,// 
ISSN 2074-7888, Наукові праці Донецького національного технічного університету, серія

"Проблеми моделювання та автоматизації проектування" №1 (14), 2019

Acustica. - Vol. 81. - pp. 196-197. 1995.

[8] Lim G.H. Effect of Edge and Internal Point Support of a Printed Circuit Board Under Vibration/ G.H.Lim, J.H.Ong, J.E.T.Penny // ASME Journal of Electronic Packaging. - Vol. 121, №2. - pp. 122-126. 1999.

[9] Ong J.H. Simple Technique for Maximising the Fundamental Frequency of Vibrating Structures/ J.H. Ong, Lim G.H. // ASME Journal of Electronic Packaging. - No 4, Vol. 122. pp. 341-349. 2000.

[10] Royzman V. The dynamic effects and shocks in electronics / V. Royzman, E. Nester // Experience of designing and application of cad systems in microelectronics. 6th International Conference of CADSM 2001, FEB 12-17. - P. 256-259. 2001.

[11] Saaty T. Decision-making. Method of analysis of hierarchies / T. Saaty. - M.: Radio and svyaz, 1993. - 320. 1993. (in Russian)

[12] Saaty Thomas L. Eigenweinghtor an logarithmic lease sguares/ Thomas L. Saaty // Eur. J. Oper. Res. -- V. 48, № 1. - 156-160. 1990. (in Russian)

[13] Saaty T.L. Multicriteria Decision Making. The Analytic Hierarchy Process: Planning, Priority Setting, Resource Allocation/ Thomas L. Saaty. - University of Pittsburgh, - 359. 1990. (in Russian)

[14] Smoliy V.N. Automation of processes of production of blocks of electronic vehicles: Monographija. - Lugansk: East Ukrainian National University named after V.Dal. - 124. 2006. ((in Ukrainian).

[15] Smoliy V.N. Case frame by production of electronic vehicle of military purpose // Scientific Papers of Donetsk National Technical University. Series «Informatics, Cybernetics and Computer Science» (ICCS - 2010). - Donetsk: DNTU. - Issue 11( 164) - 188 - 193 . 2010. (in Russian)

[16] Smoliy V.N. Hierarchy of criteria in the operations management of electronic vehicles / V.N. Smoliy // Praci Lugansk Branch of International Informatization Academy. - Lugansk: East Ukrainian National University named after V.Dal. - №1(21). - 64 - 69. 2010 (in Russian)

[17] Steinberg D.S. Vibration Analysis for Electronic Equipment. - John Wiley \&Sons. 2000.

[18] Suhir E. 2000.: Predicted Fundamental Frequency of Vibration of a Heavy Electronic Component Mounted on a Printed Circuit Board / E. Suhir // ASME Journal of Electronic Packaging. - Vol. 122, No 1. - pp. 3-5.

[19] Valiani A. Case Study: Malpasset Dam-Break Simulation using a Two-Dimensional Finite Volume Method/ A.Valiani, V.Caleffi, A.Zanni// Journal of Hydraulic Engineering. - May,Vol.128, №. 5. - P. 460-472. 2002.

[20] Ulshin V.A. Automated management by designer preparation of production of electronic vehicles/ Vitaly Ulshin, Victoria Smoliy // TEKA Kom. Mot. I Energ. Roln. - 11A. - 276 281. 2011.

[21] Ulshin V.A. Case-based reasoning method for diagnostic decision support system of bridge cranes/ Vitaly Ulshin, Sergey Klimchuk // TEKA Kom. Mot. I Energ. Roln. - 11A. - 266 - 275. 2011.

[22] Wong T.-L. Experimental Modal Analysis and Dynamics Response Prediction of PC Boards With Surface Mounted Electronic Components / T.-L. Wong, K.K.Stevens, G. Wang // ASME Journal of Electronic Packaging. - Vol. 113. - pp. 244-249. 1999.

Надійшла до редакиії 13.12.2019 p.

Smolij Victoria Nicolaevna - Doctor of Technical Sciences, Professor, Volodymyr Dahl East Ukrainian National University, (59 a, Central avenue, Severodonetsk, 93400, Ukraine).

E-mail: vmsmolij@ukr.net. 
ISSN 2074-7888, Наукові праці Донецького національного технічного університету, серія

"Проблеми моделювання та автоматизації проектування" №1 (14), 2019

\section{ПРО ОСОБЛИВОСТІ УПРАВЛІННЯ КОНСТРУКТОРСЬКОЮ ПІДГОТОВКОЮ ВИРОБЛЕННЯ ЕЛЕКТРОННИХ АПАРАТІВ}

В результаті проведених досліджень розроблена концепчія управління конструкторською підготовкою виробництвва електронних апаратів, що спирається на єдиний інформаційний простір компонування електронного апарату, оперативного управління конструкторською підготовкою виробнищтва і системи управління ресурсами підприємства, щьо дозволяє підвищити ефективність управління конструкторською підготовкою виробниитва електронних апаратів.

Сформований комплекс технічних засобів для технологічного процесу виробництва блоків електронних апаратів, який дозволяє впровадити нові науково-дослідні результати у виробництво. Запропонований критерій якості технологічного прочесу виробництва блоку електронного апарату, що зв'язує надійність виробу, щэо випускається, з його механічними, технічними і економічними параметрами.

Розроблені програмно-технічні комплекси для моделювання механічних навантажень блоків електронних апаратів $і$ складових вирімують завдання моделювання електронного апарату як об'єкту конструкторської підготовки виробництва $і$ дозволяють генерувати початкову інформацію для системи підтримки ухвалення рімень, щзо розробляється, $i$ аналізувати рішення конструкторської підготовки виробництва електронних апаратів, що приймаються.

У детермінованій постановиі рішення задачі синтезу електронного апарату 3 оптимальними вібрачійними, тепловими і механічними параметрами передбачається шляхом застосування ітерачійних алгоритмів, що по черзі відпращьовують спочатку ієрархію складових електронних апаратів, потім відповідної головної групи чинників, щзо відповідають пріоритету, що відбивас умови експлуатації, а потім безпосередньо кожного з чинників. Стохастична постановка рішення задачі синтезу електронного апарату з оптимальними параметрами в площині техпроцесу його виробництва припускає рімення задачі оптимального управління у рамках адаптивної системи за критерієм компонування, шео зв'язує параметри електронного апарату $i$ його складових з параметрами техпроцесу його виробництва. У детермінованій постановиі рімення задачі синтезу електронного апарату з оптимальними вібраційними, тепловими і механічними параметрами передбачається шляхом застосування ітераційних алгоритмів, по черзі.

Провівши дослідження особливостей моделей опису технологічного процесу виробництва електронних апаратів, слід зазначити, що в детермінованій постановиі необхідно відщукати оптимальні параметри електронного апарату, а в стохастичній - оптимальний сценарій досягнення необхідних властивостей в конкретному технологічному процесі виробництва.

Проведення експериментальних досліджень за очінкою достовірності пропонованого методу припускає дослідження техпрочесів виробництва електронних апаратів конкретних підприємств галузі з виконанням їх порівняльного аналізу, впровадженню отриманих результатів і розробки рекомендаиій і пропозицій по модернізації існуючих техпроцесів.

Сформульована мета роботи, щчо полягає в створенні методу синтезу електронних апаратів з оптимальними вібраційними, тепловими $i$ механічними параметрами в детермінованій постановці $i$ процесу проектування, щฺо забезпечує оптимальність, в стохастичній постановиі.

Ключові слова: конструкторська підготовка виробництва, електронний апарат, концепція управління, інформаційний простір, компоновка електронного апарату, оперативне управління, ресурси підприємства, система підтримки прийняття рішень.

Смолій Вікторія Миколаївна - доктор технічних наук, професор, Східноукраїнський національний університет ім.В.Даля (пр. Центральний, 59 а, м. Сєвєродонецьк, 93400, Україна). E-mail: vmsmolij@ukr.net. 